\title{
Gazing in the Eyes of the Martyrs: Four Theories of South Asian Shi'i Visuality
}

\author{
Karen G. Ruffle | ORCID 0000-0001-8289-8771 \\ Associate professor, Department of Historical Studies and Study of Religion, \\ University of Toronto, Canada \\ karen.ruffle@utoronto.ca
}

\begin{abstract}
This essay presents an extended theoretical reflection on how South Asian Shi'a visually engage with image-objects, notably the metal standard ('alam), and replica of Imam Husayn's Karbala shrine-tomb (ta'ziya). I present four theoretical lenses to theorize South Asian Shi'i visual interactions: 1. Image acts; 2. Objects as assemblages imbued with thing power; 3 . Images as focal objects of reciprocal gazing, and 4 . The intersensorial nature of image-objects.
\end{abstract}

\section{Keywords}

South Asian Shi'ism - New Materialism - visual culture - image acts - Hyderabad - 'alam ta'ziya - assemblage - Sayyid 'Ali Naqi Naqvi

Standing before the 'alams displayed each Muharram at the 'äshürkhānah Sayyid Jamshed 'Ali Khan, also known as Lohe ki Kaman, located in the Old City neighborhood of Pathar Gatti in Hyderabad, India, one gazes on the faces of the beloved Imams and Ahl-e Bayt (the family of the Prophet Muhammad descended through Fatimah al-Zahra and his cousin and son-in-law 'Ali ibn Abi Talib), dressed in royal finery. An 'äshürkhānah ("the house of the tenth"), Lohe ki Kaman is a ritual space in Hyderabad, where the majlis-e 'azā, or mourning assemblies are held to remember the martyrdom of the third Imam, Husayn at the battle of Karbala, Iraq in 680 CE. Āshūrkhānahs are also where 'alams are raised during Muharram for Shi'a to venerate and from which to seek intercession.

The 'äshürkhānah was built around 1650, during the reign of the Qutb Shahi sultan, 'Abdallah (r. 1626-72), although these 'alams were installed during the reign of the third Asaf Jahi Nizam, Sikandar Jah (r. 1803-29). Beginning around the fourteenth century, the Deccan region of south-central India was ruled by a number of Muslim dynasties. From approximately 1496, Golconda, and then from 1591, the newly constructed city of Hyderabad was ruled by two different Muslim dynasties, the devoutly Shi'a Qutb Shahs (r. ca. 1496-1687) and the Sunni Asaf Jahi Nizams (r. 1724-1948). Hyderabad was established in 1591 by the fifth Qutb Shahi sultan, Muhammad Quli (r. 1580-1612). The first buildings he constructed in his new capital were for the display of Shici relics and 'alams and for the events of Karbala to be condoled ('āshūrkhānahs). The reigns of Muhammad Quli and the seventh sultan, Abdallah (r. 1626-72) saw large-scale sponsorship of Muharram ritual in Hyderabad by the Qutb Shahi state, which resulted in the innovation of new architectural spaces for holding religious events, as well as the production of new 


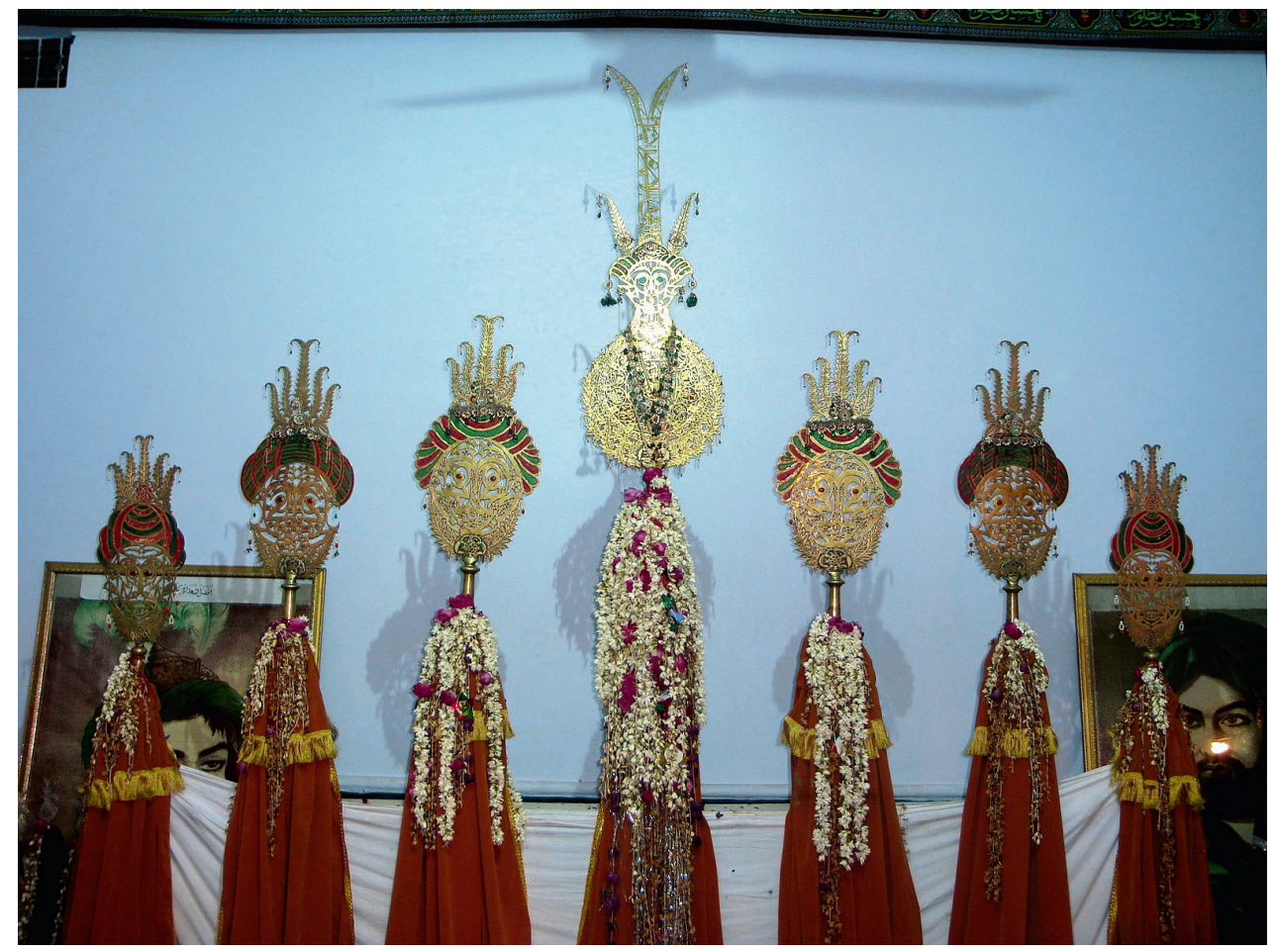

mediations of material and visual practices for instilling memory of Imam Husayn among Deccani Shi‘a. Although Sunni, the Asaf Jahi Nizams and their courtiers were enthusiastic supporters of Muharram and the city's 'āshürkhānahs, relics, and 'alams. After the collapse of the Qutb Shahi dynasty in 1687 following 'Aurangzeb's siege of the city, a revival of Muharram was propagated by the Nizams beginning in the second half of the eighteenth century. The Nizams renovated 'äshürkhānahs that had fallen into disrepair during the decades following the collapse of the Qutb Shahi dynasty when 'Aurangzeb had forbidden the observance of Muharram and had even turned the Badshahi (royal) '̄shūrkhānah into a garage (banḍi-khānah) for his bullock carts ('Azmi, 2000: 44).

The Jamshed 'Ali Khan 'Āshürkhānah was constructed in 1803 by Nawab Sayyid Mukarram 'Ali Jah, better known as Qaysar Jung, who was a minister in the court of the third Nizam Sikandar Jah (r. 1803-29). The 'āshürkhānah is located in Hyderabad's Old City. The man commissioned to make these 'alams for the 'āshūrkhānah, Ghulam 'Ali, received inspiration for the design from Imam Husayn in a dream, which happened in 1805 (Baqari, 2000: 55).

The calligraphic inscriptions and tughra designs made with these 'alams are unique in their explicit anthropomorphism (see figure 1). It is abundantly clear that you are gazing on the visage of the Imams and members of the Ahl-e Bayt, whose identities can be gleaned from reading the inscriptions and looking for other visual cues that any devotee will readily recognize. Musanna or mirrorwork calligraphy was used by the artisan ('alam-sāz) to create facial symmetry, creating two eyes, cheeks, eyebrows, ears, a nose, and mouth, as seen in figure 2.

The distinctly human features of the central 'alam are fashioned from two tughras, a smaller calligram for the head, and a larger one (the pețā) that forms the body. Rising up from the 'alam's crown across which is written the bismallah, is 'Ali's forked sword, Zulfiqār, in which is inscribed the famous saying associated with his weapon, "lā fatah illā 'Alī wa lā sayf illā Zulfiqār" in fine cutwork calligraphy. The face features eyes made of turquoise ( firüzah) and the nose and mouth are calligraphically shaped from the names of the panjetan-e pāk (Muhammad, Fatimah al-Zahra, 'Ali, Hasan, and Husayn).
FIGURE 1

Jamshed 'Ali Khan 'Āshūrkhānah, Hyderabad, India PHOTO BY SAFDAR HYDER, 2009. CREATIVE COMMONS ATTRIBUTION-SHARE ALIKE 3.0

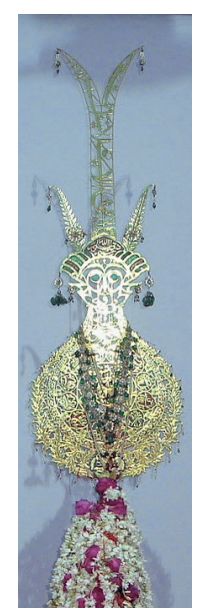

FIGURE 2

Central 'alam, Jamshed 'Ali Khan 'Āshūrkhānah, Hyderabad PHOTO BY SAFDAR HYDER, 2009. CREATIVE COMMONS ATTRIBUTION-SHARE ALIKE 3.0 
Within the peța of the 'alam the first statement of the shahadah is inscribed, there is no god but God, "lā ilāhā illā Allah," around which twelve small roundels contain the names of the twelve Imams. The central 'alam is visually complex, coalescing values and ideals of Hyderabadi normative and everyday Shicism in this image-object. The inscriptions present the viewer with condensed theological lessons that are highly typologized in their visual form. One need not be literate to understand a particular calligraphic shape and what it says. One learns that the grouping together of specific letters forms the word "Allah," and seeing this letter grouping often enough produces the ability to recognize the word by sight, if not as a result of literacy.

The head of each 'alam is topped with a series of vestments and jewels, denoting the royal status each standard is endowed. Three smaller 'alams flank the right and left sides of the large, central crest, which are adorned with green and red enamel-ware turbans ('imama). The colors used in the turbans resonate in Shici cultural memory; red symbolizes the blood shed by Imam Husayn and his supporters on the Karbala battlefield; green is the color of the Prophet Muhammad and the cause of Husayn. The turban represents the 'alams' royal status, and the red and green color symbolism indexes their Shi'i orientation. The finger-like projections extend above the red and green 'imama is another form of turban design, known as jürā or turra, referring to the crest or ornament of a turban (Platts, 2000: 396 and 752). The jüră's projections from the turban are a referent to the panjetan-e pa $k$, the "Five Holy Ones," the Prophet Muhammad, Fatimah al-Zahra, 'Ali ibn Abi Talib, Hasan ibn 'Ali, and Husayn ibn 'Ali (Parsapajouh 2020). Such number symbolism is a common motif in South Asian Shici religious architecture and in objects such as 'alams and ta'ziya. The panjetan-e pāk is replicated in the musanna calligraphy in the smaller flanking 'alams. Two diamond sarpech, turban ornaments, are embedded the jūrā. The sarpech on the flanking 'alams have a horizontal diamond base with a single vertical projection, designed in a floral motif. Each 'alam is dressed in heavy red cloth cloaks, trimmed with dark yellow fringe. The central 'alam, representing Imam 'Ali, follows a somewhat different representational program that I will return to later in the essay.

The 'alams at the Jamshed 'Ali Khan 'Āshürkhānah seem exceptional for their explicitly anthropomorphic qualities. For some, such clear anthropomorphism is in tension with assumptions about the status of image-objects in Islam. The perception that Islam is an iconoclastic religion, and that all Muslims at all historical junctures, and in all parts of the Islamic world have held antagonistic attitudes toward expressions of figural representation is but one challenge with which Islamic studies scholars have had to contend. Islamic studies scholars in art history, ${ }^{2}$ history and religious studies, ${ }^{3}$ and anthropology, ${ }^{4}$ have expanded our understanding of the central role images and objects have in Muslim religious and cultural life. Art historians have drawn our attention to the marginalized status of Islamic art history in the discipline, and recent scholarship has helped us to reconsider the meaning and role of "iconoclasm" in Islamic thought and practice. Islamic studies scholars in the study of religion have recently begun to look to the material archive as a valuable source of information for understanding Muslim social, cultural, and religious identities. The value of the work of these scholars in these different disciplinary fields is their attention to historical, cultural, and linguistic contexts and sources, which have revealed the formative meanings material culture has in Muslim religious experiences.

Attentiveness to material practices is dependent on the specificities of cultural and historical context. The reader might take exception with my singular focus on Shi'ism in the Indian subcontinent and my deliberate exclusion of Iran and the broader Shici world. This essay does not aim for comprehensiveness and does not look to Iran as the exemplum for Shici aesthetics and material culture. Many of the ocular religious practices that shape Shici ritual are imprinted by the Indic religio-cultural environment, 
of which the community is an integral part. Shica living in the Indian subcontinent inhabit multiple worlds that shape their identities - linguistic, gender, ethnic, caste, socio-economic, to name just a few - and "their religious sensibilities are shaped by Islamic laws and norms, the cultural memory of the events of Karbala, as well as a South Asian or Indic grammar of religion that animates devotional practices and traditions to the Imams and Ahl-e Bayt, which I refer to as 'Indo-Shi' ism"' (Ruffle forthcoming). Indo-Shi'ism is the result of a blending of Indic and Shi'i-Islamic religious sensibilities, practices, literatures, and normative traditions. I prefer this term to either Indo-Persian, which privileges the Persianate linguistic and cultural tradition, or Indo-Muslim, which homogenizes and reduces all Muslims to a singular entity.

Attentiveness to image-objects points to a related tension that invariably arises when engaging with Muslim material practices. Since at least the mid-nineteenth century, debates have circulated among religious scholars ('ulama $\bar{a}$ ) regarding the permissibility of erecting and taking out in procession, likenesses of Imam Husayn's Karbala shrinetomb, known as ta'ziya. ${ }^{5}$ As scholars engaged in the academic study of Islam, we see what appears to be an intractable tension between normativity and everyday Islam, two modes of being Islamic situated at two oppositional poles. In my study of South Asian Shi'ism, I posit the everyday and normativity are symbiotically intertwined (forthcoming).

In his study of the Sunni discourses on Muhammad's prophetic model among Deobandi and Barelvi thinkers in nineteenth century North India, Sherali Tareen locates the everyday within normative ideologies. According to Tareen, "Central to theorizing the category of normativity in Islam is the question of how a set of authoritative religious discourses become embodied in a community's practice of everyday life" (2020: 185). Tareen's conception of normativity surfaces a community's creativity and contingency, which Nadia Fadil and Mayanthi Fernando highlight in their critique of the recent turn in the anthropology of Islam to construct the everyday and normativity as oppositional categories (Fadil and Fernando, 2015: 69).

The concept of cultural memory serves as the performative bridge that braids together the everyday and normativity in our analysis of South Asian Shici image-objects. Cultural memory and its rituals is shaped by elite and grassroots ritual participants (agents), who, while identifying as Shi'a, may not necessary be religious, yet are influenced by the ethos and aesthetic of Karbala. The sources of everyday Shi'ism - poetry (nauhah, marsiyah), miracle stories (mu'jizat kahānī) 'alams, ta'ziya - derive spiritual inspiration and doctrinal legitimation from the tradition's normative sources including, records of the words and deeds of the Imams ( $a k h b \bar{a} r)$, compendia of law, hagiographies, and martyrdom narratives (maqtal). The success of the zākir (orator) presiding over the mourning assembly and the marsiyah poet depend on marshaling a vast literary corpus comprising knowledge of the Qur'an, hadith, Sufi texts, and Shi'i hagiographical sources. An 'alam maker ('alam-sāz) or táziya craftsman likewise must develop specialized skills in the arts, and must also be deeply knowledgeable in traditions about the events of Karbala and its heroes who are brought to life in these material objects. The everyday and the normative, therefore cannot exist in isolation; they are symbiotes.

Jan Assmann describes cultural memory as something that is explicitly material, as something "materialized and stored away in symbolic forms that, unlike the sounds of words or the sight of gestures, are stable and situation-transcendent; they may be transferred from one situation to another and transmitted from one generation to another" (Assmann, 2015: 331). Although the historical event of Karbala happened more than 1300 years ago, its memory is materialized in meaningful forms such as 'alams, ta'ziya, replicas of the cradle $(j h \bar{u} l \bar{a})$ of Husayn's infant son, 'Ali Asghar, and likenesses - both animate and figural - of Zuljanah, Husayn's faithful battle horse, are focal objects that operate as "cultural (mnemo-)techniques that support memory ... This interaction between a remembering mind and a reminding object is the reason why the realm of 
these things - especially the things meant as reminders, that is, mnemonic institutions has to be included in our concept of memory" (Assmann, 2015: 332).

In addition to the myriad forms of devotional poems and hagiographical narratives extolling the events of Karbala and its heroes, prayer-books, the diverse image-objects that support South Asian Shici memory obtain spiritual inspiration and doctrinal validation from authoritative sources, including hadith compendia, legal treatises, and theological works. Élite specialists, trained in the texts formative of the normative tradition, or working under the tutelage of scholars in those knowledge networks; or, artisans of Shi'i image-objects, for example, a Hyderabadi 'alam designer ('alam-sāz) needs to be skilled in multiple arts, including metal-working, calligraphy, and jewelry design. In an interview with the royal 'alam-maker, Janab Nizam al-Din Sahib, which was published in the August 1978 edition of the Hyderabadi Shici newspaper, Sada-ye Jafariyya, we are told the most highly accomplished 'alam artists must master multiple techniques and must possess deep knowledge of Shici theology and the Karbala event - what Assmann describes as cultural memory. ${ }^{6}$

The 'alams at the Jamshed 'Ali Khan 'äshürkhänah with their faces, jeweled eyes, and royal insignia, command the devotee's gaze. Likewise, the devotee's venerating look compels the object to look back - an issue to which I shall return in greater detail later in this essay. The 'alams displayed at the Jamshed 'Ali Khan 'āshürkhānah compel the devotee's gaze and materially shape memory of the Imams as idealized divine kings, which conforms to Assmann's theory of cultural memory and the subcontinental religious practice of mutual visual exchange (darśan). ${ }^{7}$ Like Hindus, Jains, and Buddhists who participate in rituals of reciprocal gazing with an embodied image (mūrti, tìrthaíkara, or buddharūpa), Shica also perform rituals of visual exchange with image-objects embodying the Imams and Ahl-e Bayt, known as nažr or dìdār. In what follows, I shall present four theoretical lenses through which to theorize the ways Shi'a visually interact with image-objects in South Asia. Through the first lens, we will conceptualize these objects as "image acts," which exist beyond the re-presentational power of the written word. In the second lens, we will consider how the assemblages of objects that comprise South Asian Shici material culture may be possessed of what Judith Bennett has elsewhere described as "thing power" (2010: 6). Does the non-human oriented-subjectivity of New Materialism offer new perspectives for understanding how subject-object relations shift between human and object in South Asian Shi'i devotional gazing? Our third theoretical lens shows how the structural forms, symbolic and representational motifs of the 'alam and taziya create culturally specific focal objects that promote reciprocal visual exchange (darśan or nazr). The fourth theoretical lens brings the sensorium back into focus, arguing that ways South Asian Shi'a visually interact with image-objects are intersensorial, that is, experienced by more than one sense simultaneously (McHugh 2011). Ta'ziya "Do"?

In 1996, W.J.T. Mitchell published his influential essay asking, "what do pictures want?" Mitchell acknowledges at the outset such a question might seem "bizarre, perhaps even objectionable," continuing, "I am aware that it involves a subjectivizing of images, a dubious personification of inanimate objects, that it flirts with a regressive, superstitious attitude toward images, one that if taken seriously would return us to practices like totemism, fetishism, idolatry, and animism" (Mitchell, 1996: 71). Charges of idolatry, fetishism and totemism are intended as insults and to diminish the power of images, which hold no sway with Mitchell because he considers images (or pictures) as living, social things (Mitchell, 1996: 81-2). 
Mitchell argues that as human beings, we have failed to give images a theory of their visuality commensurate to their own general features and qualities. The study of visual culture has made us aware of the social dimensions of the visual and the complex processes by which gazing is an interactive process; the visual is constitutive of our social relations (Mitchell, 1996: 82). Mitchell asserts, "Vision is as important as language in mediating social relations, and it is not reducible to language, to the 'sign', or to discourse. Pictures want equal rights with language, not to be turned into language" (1996: 82). This decoupling of the image from language is critically important for conceptualizing the representational power of different types of image-objects. How does an imageobject 'speak' or 'act' when different communicative modes are given precedence?

Image-objects are the material media in which Shi'i cultural memory is embedded, and its particular decorative forms and visual practices reflect the social and cultural frames required for this embedding (Assmann, 2015:332). Cultural memory springs from the material object's mediation of what Jan Assmann calls the "remembering mind" and the "reminding object" (2015: 332). Cultural memory is materially framed and constituted. As such, "what pictures want is not the same as the message they communicate or the effect they produce; it's not even the same as what they say want. Like people, pictures don't know what they want; they have to be helped to recollect it through a dialogue with others" (Mitchell, 1996: 81). Cultural memory and the materials that construct it, is a social phenomenon, in which things like objects have an active part.

Might we consider South Asian 'alam or ta'ziya (see figure 3), as types of Shici images, capable of engaging in the production of acts, or to be classified as actions? The anthropologist Liza Bakewell argues that images, "rather than re-represent reality and therefore be largely descriptive, are more accurately categorized as actions" (1998: 22). Image acts largely occur in extralinguistic contexts, instead emerging within visual registers that "provides the most significant portion and almost always a consequential one" (Bakewell, 1998: 23). Bakewell's theory shows its influence from Mitchell's picture theory with its refusal to separate the human from the image, blurring the line between subject and object, producer and consumer. What classifies as an image act is capacious, according to Bakewell, referring to all humanmade images (1998: 28). In the South Asian context then, ta'ziyas and 'alams are humanmade objects that efficaciously communicate with and intercede on behalf of Shi'a in their capacity as image acts.

In the 1970s, the renowned Indian religious scholar, Sayyid 'Ali Naqi Naqvi, popularly known as 'Naqqan Sahib' (d. 1988) delivered a series of lectures on the history and practice of Muharram ritual, collectively referred to as 'azādārí. These lectures addressed wide-ranging topics, including detailed accounts of the Karbala events, descriptions of the origins of and rituals associated with such objects as 'alams and taziya, and the establishment of Shici communities and their associated practices in the Deccan, North India, and contemporary Pakistan. Taziyas and their associated rituals are frequently discussed by Naqqan Sahib, and it is clear these are powerful image-objects that command Shici love and loyalty, which in return will effect miraculous, intercessory acts of healing and other forms of aid by the Imams and the Ahl-e Bayt on behalf of God.

In a lecture refuting those who object to ta'ziyas, Naqqan Sahib constructs a complex theological argument centered on the blurring between human and material, subject and object. To drive home his point for those in the audience, Naqqan Sahib, describes the material form of the ta'ziya, which I italicize for emphasis, revealing their operative power as image acts:

Thus, when the devotees of God, His Prophet and his progeny, find themselves unable to go to the shrines of the latter, their urge for expression of their inner longing makes them resort to substitute forms of satisfaction. For this, they make out miniature replicas of these shrines. That these miniatures, Tazias, are made 
of ordinary paperboards, tinsels and bamboo-stick choppings, is irrelevant to the point. Obviously, these materials are not what gratifies them. If that was the case, uncut paperboards and unshaped bamboos would have as well sufficed. It is only when these materials are meticulously labored into finished forms of Tazias, representing the Imam's shrines, that they assume a sacred significance. Thus, it is their manipulated resemblances that stir and [134] create mental associations with the originals in distant lands. These Tazias are now no more mere stray pieces of tinsel and bamboos. They are now transformed into dynamic replicas of Imam Husayn's tomb.

NAQVI, 1974: 133-4

A taziya is a manipulated resemblance that generates "mental associations" with the original "in distant lands." Sometimes, ta'ziya artists "help out" by painting miniature tableaux of the major Shi'i shrine-tombs ('atabāt-e 'àliyāt) to facilitate mental associations for devotees, as seen in figure 3 .

FIGURE 3

Ta'ziya with shrine-tomb tableaux, Karachi

PHOTO BY NABEEL JAFRI, 2019

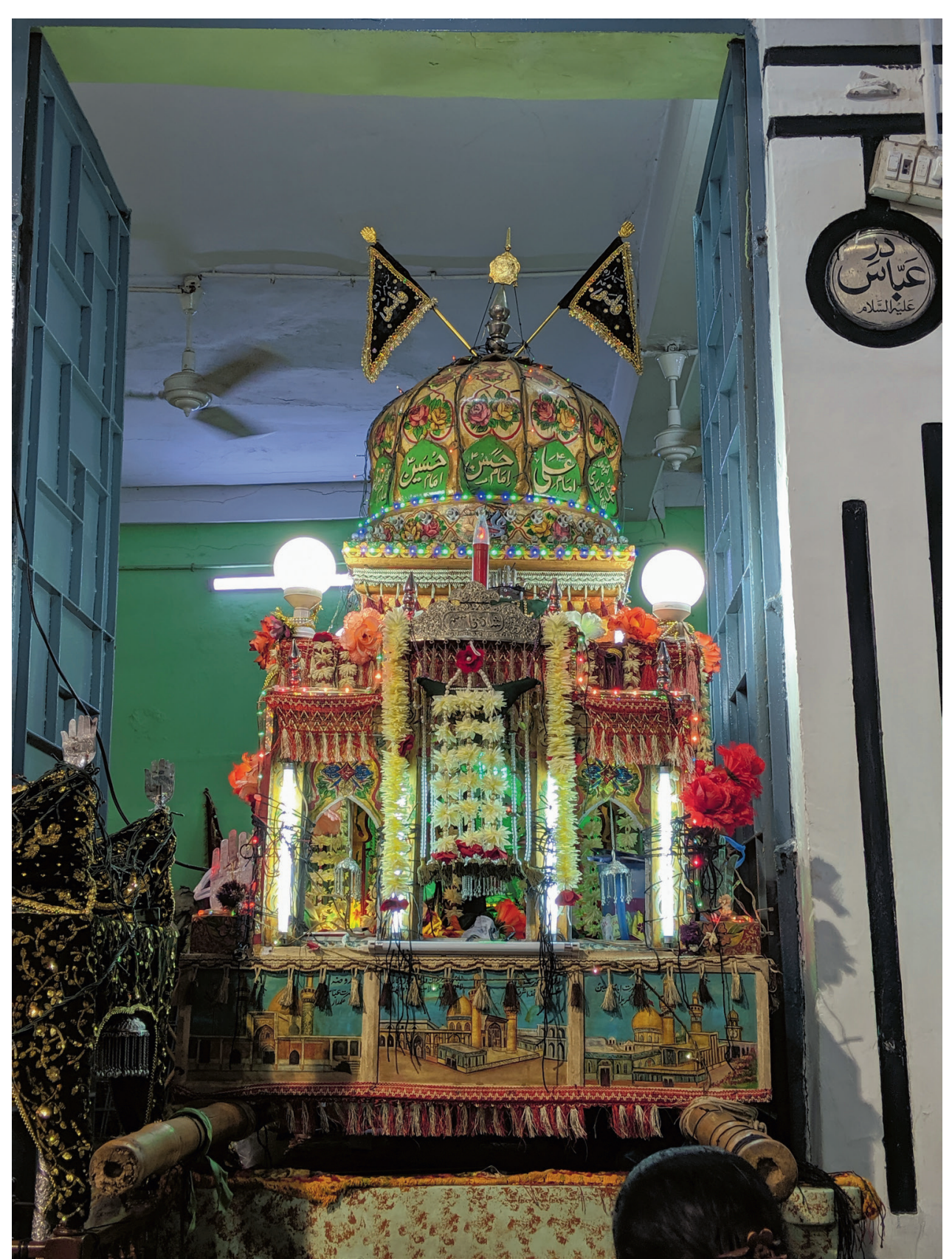

JOURNAL OF MATERIAL CULTURES IN THE MUSLIM WORLD 1 (2020) 268-290 
Nowhere is it indicated that the manipulated resemblance of the ta'ziya be an exact "likeness." In fact, it is the meticulous labor, performed as an act of love and devotion, involved in fashioning pieces of paperboard, bamboo, and tinsel that transform these things into the reminding object for the remembering mind to gaze upon and experience a form of spatial collapse, bring Karbala to the subcontinent, and bringing the devotee to Karbala.

Just as Mitchell asked in his essay, "what do pictures want," Naqqan Sahib seems to be asking a corollary question of the taziya. Mitchell posits, "Everyone knows that a photograph of their mother is not alive, but they will be reluctant to deface or destroy it. No modern, rational, secular person thinks that pictures are to be treated like persons, but we always seem willing to make exceptions for special cases" (Mitchell, 1996: 73). What both Mitchell and Naqqan Sahib show is the emotional power the object exerts over the imaginations of its interactants. We must, therefore, include aesthetics, the socially constructed "ways of feeling, forms of sensation, modes of perception," which mediate and is mediated by image acts (Morgan, 2010: 18).

\section{'Alam Assemblages: Shici Vibrant Materiality}

Alams and taziyas are image-objects that radiate a sacralized thing power, described by Jane Bennett as the "curious ability of inanimate things to animate, to act, to produce effects dramatic and subtle" (2010: 6). Thing power contends a continuity between human and non-human things, and it compels us to attend to the active role that the non-human, material has in our lives. Jane Bennett's groundbreaking book, Vibrant Matter, "re-enchants matter and materiality," (Braünlein, 2019: 622), finding energetic vitalities in unlikely and often overlooked assemblages of things, "not entirely reducible to the contexts in which (human) subjects set them" (Bennett, 2010: 5). Bennett's re-enchantment of materiality reflects the New Materialism movement that calls the subject-object binary into question. Emerging from feminist theory, cultural theory, philosophy, and the history of science in the late-199os, New Materialism is an interdisciplinary field with strong political and theoretical commitments to reframe the way matter and ideas are constructed and to radically reshape human-centered binary thought. This awareness, sensitivity, even, is echoed in Bennett's charge: "The ethical task at hand here is to cultivate the ability to discern nonhuman vitality, to become more perceptually open to it" (2010:14).

In being more open to the agency wielded by non-human matter, endowed with "trajectories, propensities, or tendencies of their own" (Bennett, 2010: viii), we can also see where there is the potentiality for tensions to arise in Islamic contexts in endowing objects with the ability to see and be seen, and to have different forms of agency. On the surface, it seems that the notion of Islamic vital materiality might be contrary to the qur'anic prohibition, shirk, against associating any being or thing with God: "Worship God, and do not associate any others with him" (4:36). Associating things with God is the tantamount violation one can commit as a Muslim, and it is the primacy accorded shirk that upholds the theological premise of Allah's uniqueness. The theological principle of shirk is premised on boundary making and maintenance, of delineating the civilizational status accorded by receiving divine revelation and a book of law, and those living under the sway of the idol and fetish. Within the fetish, and by extension, the idol, "power was ascribed to an object such that agency was not reserved for human subjects but was also resident through the material world. In defining other, 'less advanced' religion, it was in large part the stuff they had, and the powers invested in and exercised by that stuff that made the distinction stick" (Orsi 2012; quoted in Promey, 2014: 8). 
The immediate recourse to shirk, or that such practices as erecting 'alams or displaying ta'ziyas are forms of bid'ah, innovation, which exceeds the normative practices established by the Prophet Muhammad. I caution against labeling such material practices, with their deep historical roots and ritual currency transecting gender and socio-economic lines. Labeling ta'ziya and 'alams and other forms of South Asian Shici materiality as shirk or bid'ah has become for some, "a rhetorical sledgehammer to vindicate their own ideas by obliterating others" (Tareen, 2020: 180). The rhetorical sledgehammer, in this instance, aims to perform a sort of ideological iconoclasm, to deny the vital materiality of the 'alam. New Materialism challenges this tendency because of its recognition of nonhuman vitality in all things, not just the idol and fetish. How then, do we understand the vital materiality of an 'alam?

To develop her theory of thing power, Bennett draws on the postmodern environmental philosophical writing of Gilles Deleuze and Félix Guattari to postulate metal as the symbol of vital materiality. Shici material culture is a metallic materiality - brass, silver, and steel 'alams, inexpensive foil-work pocket-size panjahs (palm with the fingers extended) and Zuljanahs, metalwork ta'ziya and jhülā cradles - are all "quivering evanescence ... metal, bursting with a life, that gives rise to 'the prodigious idea of Nonorganic Life"' (Bennett, 2010: 55). This material evanescence exists prior to and beyond its formation and spatial arrangement in assemblages, which derive their agency from their heterogenous distribution across human and non-human fields.

In A Thousand Plateaus, Deleuze and Guattari point to the matrix in which metal as material form is transformed in the relational context of the assemblage:

So how are we to define this matter-movement, this matter-energy, this matterflow, this matter in variation that enters assemblages and leaves them? It is a destratified, deterritorialized matter. It seems to us that Husserl brought thought a decisive step forward when he discovered a region of vague and material essences (in other words, essences that are vagabond, anexact and yet rigorous), distinguishing them from fixed, metric and formal, essences. We have seen that these vague essences are as distinct from formed things as they are from formal essences. They constitute fuzzy aggregates. They relate to a corporeality (materiality) that is not to be confused either with an intelligible, formal essentiality or a sensible, formed and perceived, thinghood. This corporeality has two characteristics: on the one hand, it is inseparable from passages to the limit as changes of state, from processes of deformation or transformation that operate in a spacetime itself anexact and that act in the manner of events (ablation, adjunction, projection ...); on the other hand, it is inseparable from expressive or intensive qualities, which can be higher or lower in degree, and are produced in the manner of variable affects (resistance, hardness, weight, color ...) There is thus an ambulant coupling, events-affects, which constitutes the vague corporeal essence and is distinct from the sedentary linkage, 'fixed essence properties of the thing deriving from the essence, 'formal essence-formed thing.'

DELEUZE AND GUATTARI, 1987:407-8

For the 'alam-maker ('alam-sāz), there is a humming, metabolic essence intrinsic in the metals used to fashion the auspicious panjah representing 'Abbas or the panjetan-e pāk, or who feels the calligraphic forms inherent in a sheet of brass, on which calligraphic tughras with Shi'i prayers, the names of the Imams, God, the Prophet, and Fatimah may be worked using pin-pricks, open-work, or embossing to bring forth its spiritual and material vitality. Drawing on Bennet's theory of thing power, I observe in my forthcoming monograph Everyday Shicism in South Asia, "The objects that comprise South Asian 
Shici material culture - brass and silver 'alams, metalwork ta'ziyas and jhülā cradles, and small portable panjahs and Zuljanahs made of foil - are "quivering evanescence ... metal, bursting with a life, that gives rise to "the prodigious idea of Nonorganic Life"” (Bennett, 2010: 55; quoted in Ruffle forthcoming).

An 'alam-maker's artistic prowess is achieved through a bridging of his devotion to the Imams and Ahl-e Bayt, an understanding of religious principles, and an understanding of the material vitality of the metals with which he works. In her fieldwork with 'alam-makers, Sarover Zaidi has noted this balance, although not in relation to New Materialism: "He calls this sustenance barkat, which literally translates as a blessing, which is seen here as a gift and an abundance of skill given to him ... Continuity between the forms of abstraction, viz., the force of the Prophet's family, here provided by the making of panjatans which represent the family, and forms of particularization, creating the material object, gather smoothly at the level of the artisan. He suggests to us in his existence a double signification, accepting on one side the materiality of this artifact and hence its iconicity and idol nature, and yet simultaneously locating all the skill, labor, work, craftsmanship within a theological language and framework of barkat" (Zaidi, 2016: 89). The materiality of the metal is felt and fashioned in dynamic relationship with Shici theology to create particularized types of 'alams that instantiate specific Imams and the Ahl-e Bayt. Material (metal) and immaterial (theology) are worked by the artisan to create a new form, the 'alam, which has its own capacity to act in relation to human beings. As Talal Asad has observed, "the power of things - whether animate or inanimate - is their ability to act within a network of enabling conditions ... Feeling, remembering, hoping as physical as they are mental" (Asad, 2005: 213; quoted in Promey, 2014: 8).

With its emphasis on a non-dualist, non-human-centered, subject-object resisting binary, the New Materialist theories encourage us to consider new conceptions of materiality and the gaze. New Materialism re-orients human perceptions of our relationship with the material world, which necessarily requires a reconceiving of how vision is ordered. The heterogeneity of the assemblage places humans in broader networks of image-objects, in which we are intimately connected through acts of multidirectional gazing. In figure 4 below, an assemblage of five of the eleven 'alams erected during Muharram at the Husayni 'Alam 'Āshürkhānah are on display. This assemblage seems to intentionally lack a twelfth 'alam since Imam al-Mahdi remains in Occultation (al-ghaybah al-kubrā). The principal image-object in figure 4, standing at the center of the photo, with its emerald (zumurrud) eyes, exaggerated sword-like extension (jibh, "tongue"), and lavish garlands around its "neck" (borī), reflects its status as a reliquary 'alam. The relic, Imam Ja'far al-Sadiq's double-edged sword was recovered by a Hyderabadi man, Agha 'Ali while he was on hajj. Agha 'Ali gifted the sword to the fifth Qutb Shahi sultan, Muhammad Quli (r. 1580-1612), who commissioned the construction of an 'āshürkhānah located approximately two miles to the west of the Charminar located at the center of Hyderabad's Old City, and appointed Agha 'Ali to place the relic within an 'alam so it might be publicly displayed during Muharram. Muhammad Quli bestowed the 'alam with the insignia of Indo-Shi'i kingship: the ensign of the fish (māhi marātib), the royal parasol (chatr), and naubat kettledrum ('Azmi, 2000: 41).

These 'alams are made of exquisitely worked brass, the central standard adorned with emeralds (zumurrud) flanking sharja, the exterior tubes that flare up each side, manifesting in zoomorphic forms that find their origins in Shi'i hagiography and Indo-Persian imperial iconography. The dragon, known colloquially as makara or crocodile in Urdu, symbolizes 'Ali's twin-tongued sword Zulfiqār, the battle-vanquisher. The dragon's gaping mouth symbolizes Zulfiqār's forked blade, and the unfurled tongue creates a sense of awe and wonder in the imagination of the devotee. The emerald eyes symbolize the

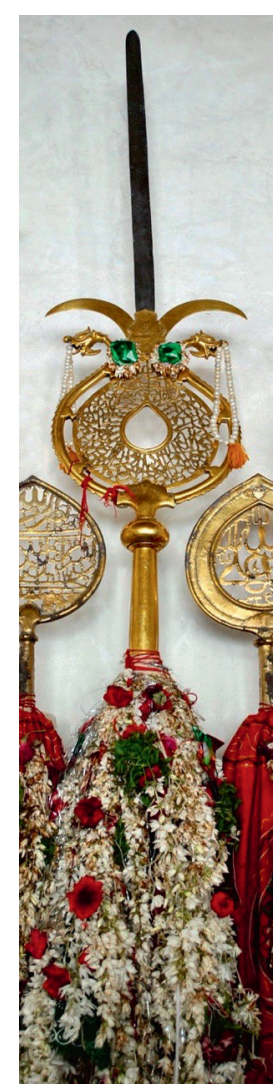

FIGURE 4

Husayni 'alam, Husayni 'Alam 'Āshürkhānah, Hyderabad Pното BY AUTHOR, 2015 
inherited spiritual authority of the Imams. Pearl necklaces take the form of earrings, draped from the mouths of the dragons, which according to the royal 'alam-maker to the Sunni Asaf Jahi Nizams (r. 1724-1948), Nizam al-Din Sahib, "This symbolizes that the Alam is to commemorate Bibi Sakina" (Sada-ye Jaffariyya, 2000: 110). While Nizam alDin's assertion that earrings indicate an 'alam is dedicated to Sakina, the central 'alam, here at Husayni 'Alam is not dedicated to Imam Husayn's youngest daughter.

I contend that earrings, whether in the forms of strings of pearls, or jeweled pouches instead indicate the reliquary status of the 'alam. This central 'alam contains Imam Ja'far al-Sadiq's sword, which was recovered by a man named 'Ali Agha, who was on pilgrimage in the Hijaz. He returned to Golconda, where he embedded the sword into an 'alam - a common practice in Hyderabadi Shi'ism - and bestowed it as a gift to sultan Muhammad Quli Qutb Shah (r. 158o-1612), who made Ali Agha the caretaker of the relic (Naqvi, 20o6: 39). With their conforming to a "reliquary script," Hyderabadi Shici relics are often lost-found objects, recovered by pious individuals through dreamtime encounters while on pilgrimage (Ruffle, 2017:337-8). The relics made their way back to Golconda-Hyderabad, where they were gifted to the sultan, who distributed their thing power by embedding the object into 'alams, many of which are arranged in heterogeneous assemblages of crests, which draws the gaze to the reliquary standard.

In the 'alam assemblage in figure 5 , human subject and non-human object do not adhere to a clear divide. Who/what is the subject and who/what is the object? Who is seeing and who is being seen? As I have argued elsewhere, in South Asian Shici material practice, "the indexing function of the 'alam, allowed it to assume a symbolic reliquary status. All 'alams became reliquary because of their indexicality. An 'alam representing Sakina, for example, does not require a relic to invoke her presence, which is invoked through intense ritual interactions. Gazing lovingly at the stylized form of the 'alam, making offerings of flowers and incense, and proffering prayers and kisses bring Imam Husayn's orphaned daughter into the 'āshürkhānah. Even without a relic embedded into the metal form, the 'alam is possessed of Sakina's personality and manifests her

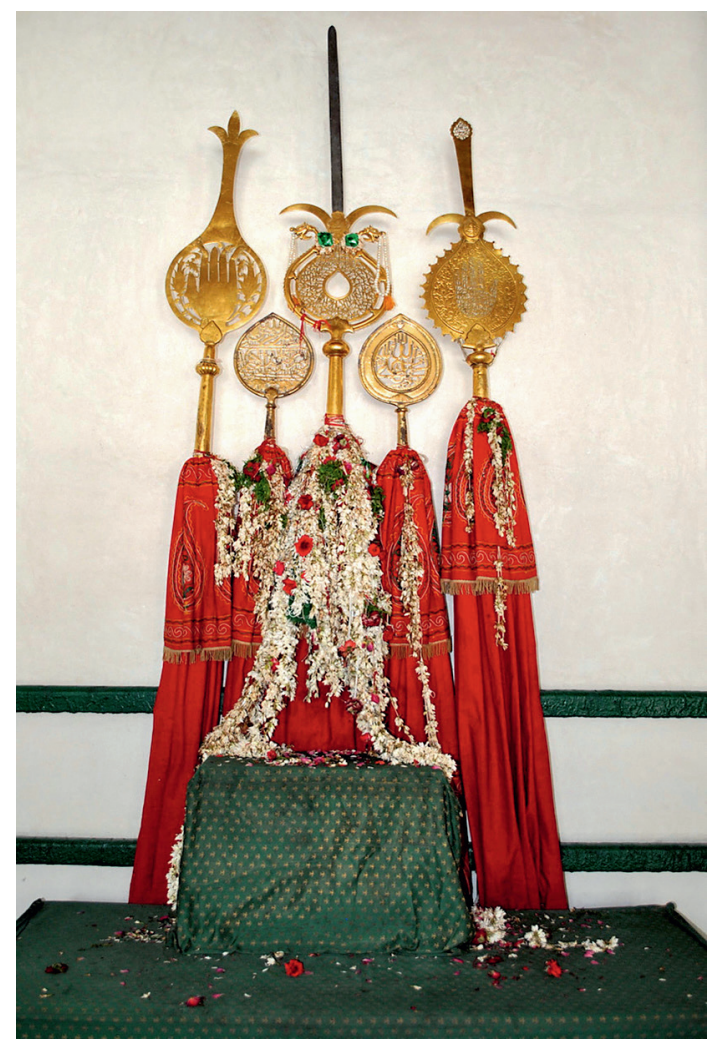

FIGURE 5

Husayni 'alam assemblage, Husayni 'Alam 'Āshūrkhānah, Hyderabad

PHOTO BY AUTHOR, 2015 
presence in absence; it is a reliquary 'a lam" (Ruffle, 2017:336). Important here is the idea that the 'alam is possessed of an Imam or member of the Ahl-e Bayt's persona. Gazing on the 'alam that vibrates with material evanescence and intercessory power shifts the subject-object divide. The shift of the subject-object divide is observed by Michel Boivin in his survey of recent scholarship on South Asian Muslim pilgrimage studies:

The reluctance in using the word, which translates the Arabic-originated word of ziyarat, better translated as 'visitation', reflects a number of questions belonging to the field of Islamic studies. In her glossary, Shemeem Abbas defines ziyarat as the 'ceremonial viewing or attendance where the devotee offers fateha (prayer) for the dead saint' (Abbas, 2002: 159). She thus focuses on the process of viewing among Sufis in South Asia, which is also known as dìdār (mystical vision) or darshan in the Hindu context. Similarly, Kelly Pemberton translates ziyarat as pilgrimage, then adds that it is 'used to describe the display of relics said to have belonged to the Prophet Muhammad' (Pemberton, 2010: 211).

BOIVIN, 2017: 63

Such ziyarat practices focus on visual interaction between the devotee and imageobjects present for ceremonial (and intercessory) viewing. The saint, the shrine, and the image-objects it holds, like the 'alam is the subject receiving the petitions and prayers of the devotee, who is the object of his or her intercessory loving compassion. The 'alam gazes back at the devotee, however, it is not the human being who has the power. As Sonia Hazard has astutely observed, "humans and things are fundamentally co-constitutive" (2013: 65).

Presence and Focal Objects: Material Mediations of the Imams and Ahl-e Bayt

In South Asia, two types of replica shrine-tombs can be found, ephemeral and permanent. Ephemeral taziya are often made by families and neighborhood associations from inexpensive materials, tinsel, brightly colored paper, and other decorative items applied to a lightweight bamboo frame. These are displayed in people's houses and in open-sided shelters (pandal, see the example of the 'alams displayed in the streetside structure in Hyderabad in figure 6) until 1o Muharram, when they are taken in procession to the local karbalā for burial or immersion in a body of water in a ritual known as thand ā karnā (to cool).

Permanent ta'ziya and 'alams are found in the domestic imāmbārās ("the mansion of the Imam") and imāmbārgāhs ("the court of the Imam") of élite Shi'a in North India and Pakistan, and these are ritual spaces where the Karbala event is narrated to devotees. These objects are considerably larger and composed of more durable and expensive materials than those used to make ephemeral ta'ziya. Permanent ta'ziya are sometimes multiple stories in height, their frame elaborately carved out of wood, over which elaborate metalwork designs may be embossed or hammered. The finest of these ta'ziya may have bright enamelwork, painting, and semi-precious gems set into the metalwork. These taziya follow highly stylized motifs that tend more toward the Sufi dargāh, and even the form of the Hindu temple (mandir), rather than anything that would immediately bring to mind the architectural styles of the 'atabāt-e 'aliyāt, located in Iran, Iraq, and Syria (Abbas, 2007: 9).

'Alams and permanent ta'ziya have commensurate representational power. Permanent ta'ziya bring the devotee close to the Imams and Ahl-e Bayt, and their large 
FIGURE 6

Pandal with 'alams, Hyderabad PHOTO BY AUTHOR, 2015

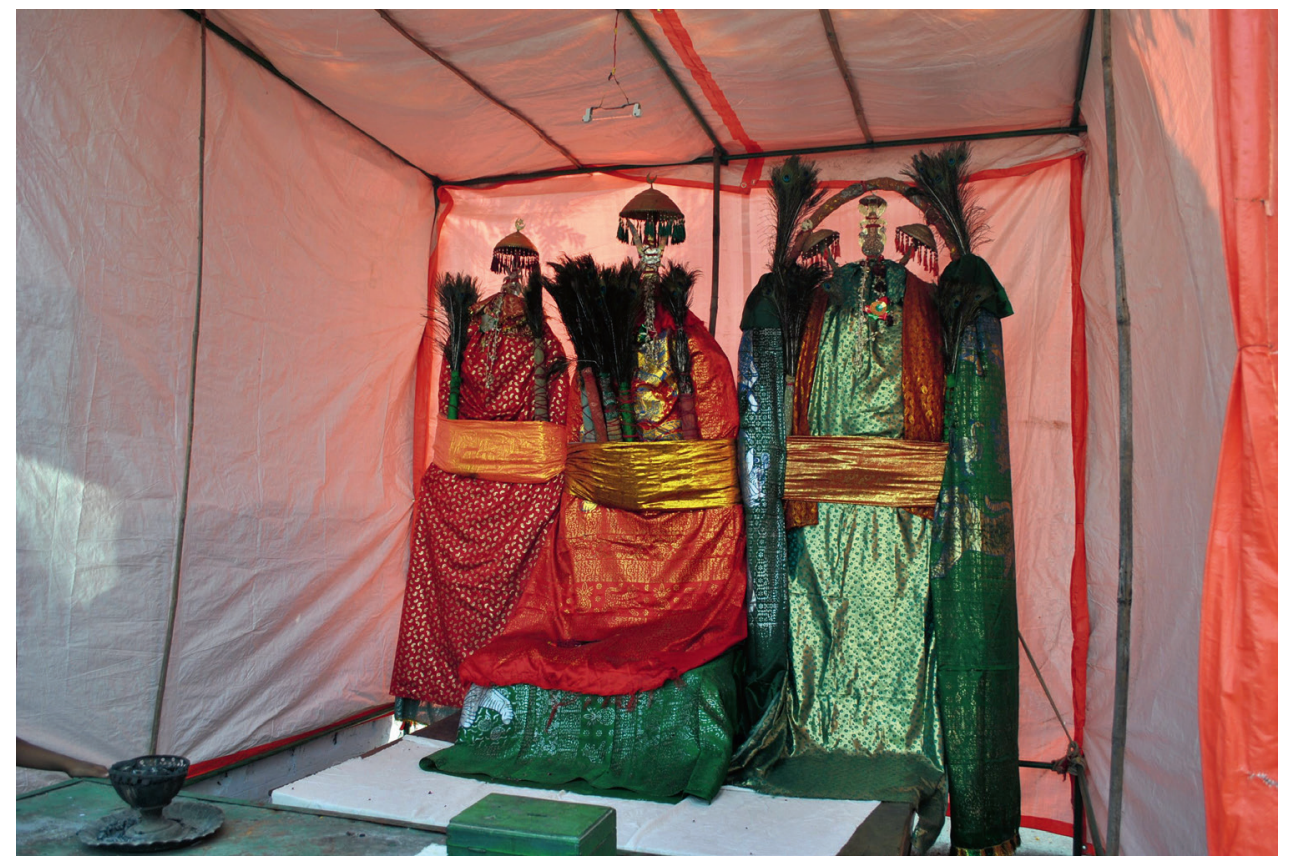

size enables them to be "focal objects" by which they "meet the eye of the viewer as a corresponding other" (Morgan, 2014: 93). David Morgan further explains that focal objects "mediate a sacred other by giving it a face," "which structures a two-way visual relationship" (2014: 83). I return to Naqqan Sahib's discourse defending the taziya in which he explains the emotional motivations that cause devotees to create shrine-tomb replicas: "It is an undeniable phenomenon that love always flows in the direction of its object; and if the object, for one reason or the other, happens to be beyond its reach, it contends itself with an Image of the object it cherishes ... their urge for expression of their inner longing makes them resort to substitute forms of satisfaction" (1974: 133). We gaze with a spectrum of emotions upon those whom we love. In the absence of a loved one, we look at her or his photo, or another object that we associate with that individual. Love, Naqqan Sahib correctly observes, is directed toward a focal object.

How might a ta'ziya enact proximity between devotees and Imam Husayn, embodied in the object? Permanent taziya are large and heavy, making them difficult to carry in crowded Muharram processions (julūs), where myriad obstacles, including men performing bloody self-flagellation with blades (zanjīr kā mātam) must be navigated. Although many of the larger, heavier ta'ziya have "feet" or "legs" on which it can rest when its carriers tire, the potential that it might become damaged, whether by accident or ill-intention, during a procession is significant. Most permanent taziya are multistory or multi-level constructions, topped with a dome (gombad) or cupola (qubbah). A permanent ta'ziya damaged beyond repair in a Muharram procession is anthropomorphized by the title, shahid (martyr), and through the ritual burial it is given in a cemetery (Lyons, 2015: 223; see also Ruffle forthcoming). A taziya whose damages can be fixed is known as a "partial" shahid (martyr), and it is usually retired from future processions. While the taziya is a focal object of loving devotion for Shi'a "because the object is in some sense personified as a victim of the Karbala debacle, a ta'ziya's dome (representing its head) is the particular target of ill-wishers" (Lyons, 2015: 223).

The personification of the taziya's dome into representing a head - and therefore, a face - provides a focal object for a specifically South Asian "nazranic" practice of auspicious gazing, that brings devotee and Imam together to see and be seen (Ruffle forthcoming). I am here employing a deliberately strategic move shifting our analytical gaze 
from the Hindu-centric "darśanic" to the term "nazranic," by which I intend to place emphasis on Indo-Shici visual practice. The "face" of the taziya is a manifestation of presence that instills feelings of love in the devotee. This sentiment is captured in the Roman emperor Julian's Oration on the Mother of the Gods in his canny explanation of the mutual gaze (and its effects) that occurs between the devotee and the gods, who gaze back from the "unseen" beyond: "It follows that he who loves the gods delights to gaze on the images (agalmata) of the gods, and their likenesses (eikonas), and he feels reverence and shudders with awe of the gods who look at him from the unseen world" (Francis, 2003: 585).

Focal objects, are intrinsically visual and material because they serve as reminding objects for remembering minds. The emperor Julian's observation that the devotee, gazing on the image and likeness of the gods, feels awe and reverence, knowing they are "somewhere else, but feels the presence of [their] visitors," and they likewise feel the gods looking from somewhere beyond (Morgan, 2010: 24). I am reminded of the assemblage of 'alams from the Jamshed 'Ali Khan 'äshürkhānah with their calligraphic eyes embedded with carnelian ('aqiq), yet some Hyderabadi 'alams prompt the reciprocity of the gaze with even more explicit ocular placements, as seen in figure 7 and figure 8 .

The installation of "eyes" into these calams, I contend, disrupts the conventional subject-object divide. The eyes embedded in the 'alam create a face on which a devotee can direct the gaze, which facilitates prayers and petitions for intercession and assistance - these are the focal points on which one can structure ritual action, acting out one's needs and desires. According to David Morgan, "Focal objects are the face of the network, the shape in which an assemblage comes to be seen ... the focal object makes the network usable, visible, accessible to the ritual exchange" (Morgan, 2014: 97).

When we pay attention to the slippage between non-human subject and human object in the operationality of the focal object, we understand that it is fundamentally rooted in an asymmetry of power. The focal object, as the representational embodiment

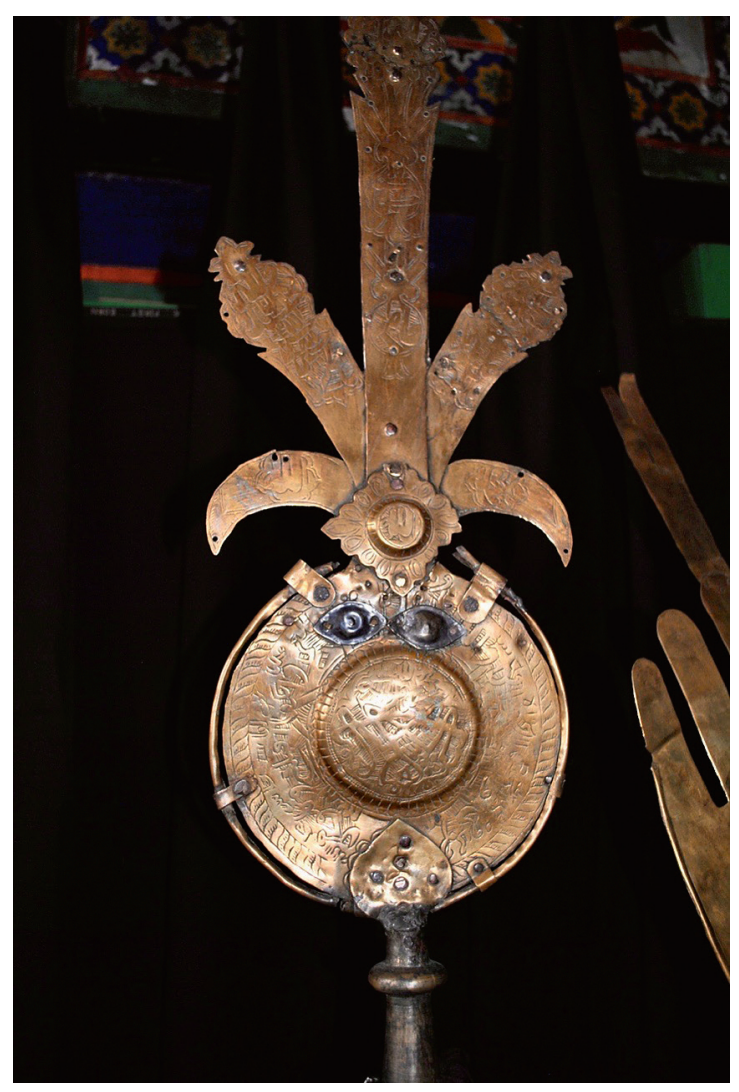


FIGURE 8

Panjah, Qutb Shahi '̄̄shūrkhānah, Hyderabad

PHOTO BY AUTHOR, 2015

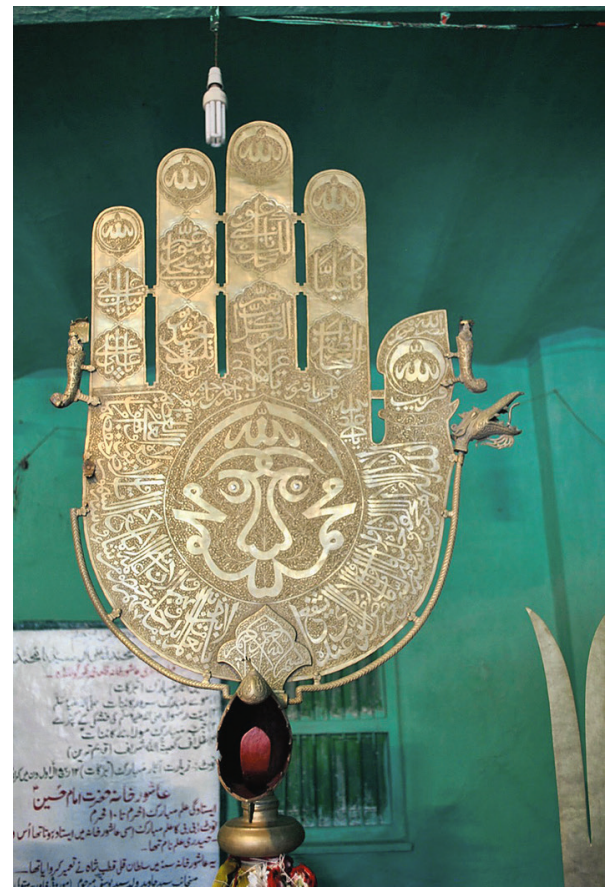

of the Imams or a member of the Ahl-e Bayt exists on a different spiritual and ontological plane of existence from the devotee. Viewing is one means by which the spiritual subject and the petitioning object-devotee can achieve a sort of mediation. In this relationship of unequals, "The viewer is subject to them [the god], but they allow themselves to be seen. They must, since by seeing the viewer recognizes them and thus acknowledges their power. Seeing and being seen, in this instance, are the respective roles in a power relationship that binds both viewer and viewed into one manifestation of civil and cosmic order, parts of a transcending whole" (Francis, 2003: 590). For the Shi'a, image-objects are material conduits to experience and make present Karbala, Imam Husayn, and the Ahl-e Bayt.

\section{4 \\ Feeling the Imam's Gaze in the South Asian Shici Religious Sensorium}

For South Asian Shi'a, Muharram rituals and their associated objects, 'alams, ta'ziya, Zuljanah, and 'Ali Asghar's cradle, are what Birgit Meyer calls "sensational forms" (2006: 9). These sensational forms are part of what I refer to as the religious sensorium, a symbolically rich socio-religious space where ritual practitioners engage with material objects and the body to produce sense-inflected cultural memory of Karbala, the Imams, and the Ahl-e Bayt (Ruffle forthcoming).

South Asian Shi'i Muharram and its associated rituals is a smelly, noisy, tasty, tactile, and visual extravaganza involving a variety of image-objects that metonymically make the Imams and Ahl-e Bayt present, while also collapsing time and space for devotees for whom Karbala and the subcontinent, for a short time, become the same place. The South Asian Shici religious sensorium is intersensorial because of its very materiality. David Howes correctly argues, "that material culture, in addition to materializing social relations and symbolizing the cosmos, gives expression to a particular set of sensual relations" (2006: 161). If we look at the materiality of South Asian Shi ism, we see that vision is distinctly intersensorial, involving other senses, particularly touch, and audition. 
Here, I would like to think about the meaning of vision in the Indic and Islamic sensorium respectively. In his study of Sanskrit treatises on perfumery practices in Hindu temples, James McHugh has noted the intersensory qualities of perfumed pastes. According to McHugh, "the multisensory nature of odorants is one well-known historical South Asian theory of smell and odors, namely, the notion that smell is the special quality of the element earth, an idea associated with some early schools of thought that we might call Hindu. According to this theory, the element earth, and things containing the element earth, can be perceived by all the senses" (2011: 165). Therefore, that which we can smell, we can see. The Indic sensorium extends the intersensory quality of vision as a form of touch:

In both Vedic and everyday Hindu practice ... looking, glancing, or casting one's eyes upon another are powerfully charged acts that can bring good or evil. According to Jan Gonda, in South Asia, looking is a form of touch, and is part of what he refers to as "the language of the eyes" (1969:4). According to Indic theories of the sensorium, human sensations do not operate in isolation, rather contact results "from a combination of 'looking' and 'touching'. Casting one's eyes upon a person and touching him were related activities" (Gonda, 1969:19). Muslim modes of seeing are similarly intersensorial, linking together the tactile and visual senses to effect contact between human and divine forces (Ruffle forthcoming 2020).

In the Islamic sensorium ( jāye hiss), vision is ranked as the supreme sense. According to Hunayn ibn Ishaq al-Ibadi, the ninth century Iraqi physician and translator of Greek medical and scientific treatises into Arabic and Syriac, "This spirit is of the sensitive variety, as vision is unique among the senses, the noblest of them and most superior in quality" (1928: 28). Some Muslim theorists of the Islamic sensorium seemed to consider vision to have haptic qualities in which the object that is gazed upon is touched by the brain and experientially "sensed," pointing to the intersensorial nature of perception. This is in contradiction to the theorization of scholars like Abu Hamid al-Ghazali (d. 1111) who perceived the senses as operating in isolation from one another: "As that which is perceived by the eye has not relation to voice, and as that which is perceived by the ear has no relation to form, and as that which is perceived by the sense of smelling has not relation to taste, so that the one can only be known by means of the other, in the same manner that which is perceived through the medium of the mind or of divine power, cannot be perceived by the senses" $(1873,46)$. Although he is explaining how God exists in all things, while also existent as Transcendent Reality beyond human comprehension, al-Ghazali clearly conceives of the senses as independent from one another. For al-Ghazali, no one sense ranks higher than the other because each performs its sensory task individually.

For other Muslim theorists, the religious sensorium extends beyond the body. In his 2012 dissertation, "Muslim Distinction: Imitation and the Anxiety of Jewish, Christian and Other Influences," Youshaa Patel accounts for the elevated status of vision and audition explaining, "Optic and sonic waves can cross over long distances and orient a sensible person to the world around her;" moreover, "Observation and listening are usually prerequisites to imitation" (2012: 379). Smell, taste, and touch, on the other hand, are theorized as the "nearer" senses, closer to our physical selves, our base needs, and the external, polluting world. In the South Asian Shici religious sensorium, ritual practitioners participate in Muharram events with deep sensory awareness. W.J.T. Mitchell describes the intersensory as "braiding, when one sensory channel or semiotic function is woven together with another more or less seamlessly" (2005: 262).The senses generate feelings that are woven seamlessly together with image-objects and their associated 
(visual) practices that are rooted in a process of integrating the materiality of the cultural memory of Muharram and its ritual practices with its very intersensoriality.

As Victor Buchli has noted in his own work on vision and presence, "the physical artifact is merely a conduit, where propinquity, nearness, is achieved haptically through an icon" (2010: 19o). According to both Indic and Islamic theories of vision, looking and touching are fully integrated activities. The act of viewing the 'alam has been referred to by the religious studies scholar David Pinault as darśanic. Pinault's definition of "darshanic religion," including Shi ism, "involves seeing ... It is imagistic in orientation, permitting one to have direct contact with the sacred" (2001: 18). Simply looking at a metallic 'alam or ta'ziya, while indexically pointing back to the Imam or member of the Ahl-e Bayt whose presence it invokes, such as the panjah or upraised palm, representing 'Abbas whose arms were severed while collecting water at the banks of the Euphrates River, is deficient according to the intersensorial logic of the Indo-Shi' i sensorium. How can one gaze upon the absent, yet present, Imam or member of the Ahl-e Bayt without being able to look into his or her "eyes," and feel that presence? How can one make an offering, or nazr, without being able to intimately, dynamically, and reciprocally see the Imam? It is significant that on Urdu word for the act making vows to the Imams and Ahl-e Bayt in the material forms as 'alams and ta'ziyas, nazr, is a homonym for a common Urdu term, $n a z r$, that is used for the mutual visual exchange between devotee and the imageobject. The visual etiquette of the Indo-Shici practice of $n a \underline{z} r$ or dìdār (and its Indic analog darśan), requires the haptic exchange of the gaze between god/Imam and devotee. In the Shi'i context, the performance of making vows and supplications (nazr o niy $\bar{a} z$ ) before the 'alams is dependent on the touch of the devotional gaze, as demonstrated in figure 9 .

In figure 9, we see a Shi'i man facing the 'alam-e sarțauq in Hyderabad's Alāvā-e Sarțauq Mubarak 'Āshūrkhānah in Dar al-Shifa', representing the fourth Imam, Zayn

FIGURE 9

Prayer to 'alam-e sarțauq, Alāvā-e Sarțauq Mubarak 'Āshūrkhānah, Hyderabad

PHOTO BY AUTHOR, 2006

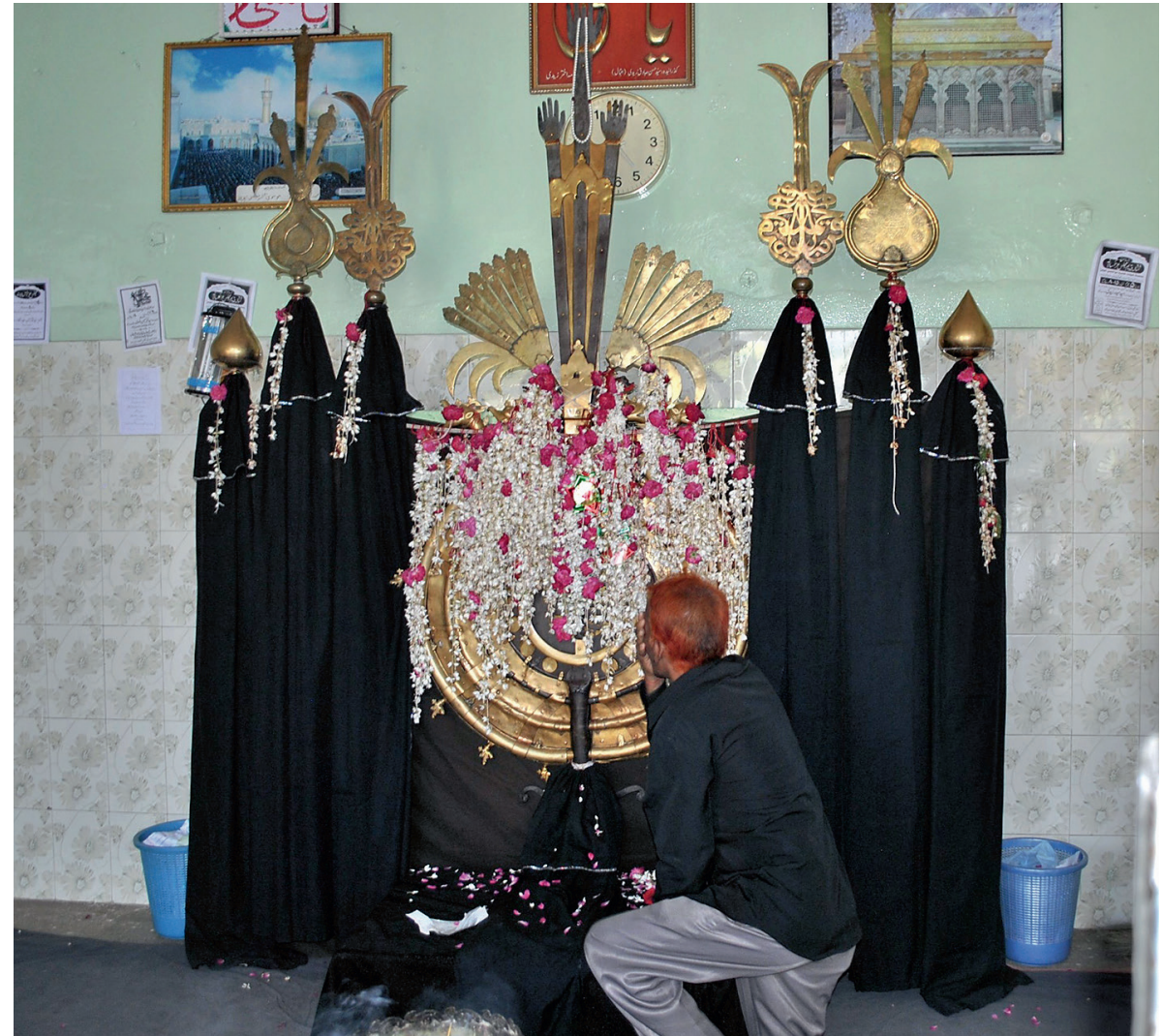


al-Abidin. This reliquary 'alam contains a piece of the shackle (tauq) that was placed around Zayn al-'Abidin's neck when he and the women survivors were marched barefoot from Kufa to the Umayyad caliph Yazid's court (darbār) in Damascus, where he attempted to heap further humiliations on the Ahl-e Bayt for the massacre of their family at Karbala. ${ }^{8}$ The relic was brought to Hyderabad during the reign of sultan 'Abdallah Qutb Shah (r. 1626-72), who had it embedded in a large 'alam that was installed in the city's free Unani hospital, Dar al-Shifa', so that the sick could seek Imam Zayn al-'Abidin's intercessory powers, in his capacity as "bìmār-e Karbala" (Karbala's sick one), to cure their ailments (Naqvi, 2006: 47). Even today, unlike most of the city's 'alams, the 'alam-e sarțauq remains installed throughout the year for the public's benefit. In the photo, we see the man faces the 'alam, his eyes are clearly engaged in an act of reciprocal gazing. It appears that in the moments before I snapped the photo, he partook in an act of physically touching the 'alam, as he is wiping his hand over his face, distributing its healing power and barakat (blessing) over his body. For South Asian Shi'a, image-objects are material conduits that facilitate seeing the past and feeling the Imams in the present.

\section{$5 \quad$ Conclusion}

In this essay, I offer an extended theoretical reflection on the ways South Asian Shi'a visually interact with religious image-objects. This essay reflects long-term research I have conducted on the ways in which material objects and their associated practices shape South Asian Shici religious lives and identities. This research has encouraged me to think deeply about how the South Asian Shi'i religious sensorium operates and by what principles, inclusive of aesthetic, material cultural, and theological principles, to name but a few constitutive factors.

The gaze, of seeing and being seen, is oriented toward eyes installed in a Hyderabadi 'alam or the cupola (qubbah) that is a ta'ziya's head. The carnelian eyes set into their calligraphic sockets in the 'alams in the Jamshed 'Ali Khan 'āshürkhānah glow, compelling you to lock eyes in a spiritual embrace. A slippage between human subject and nonhuman object occurs in this act of reciprocal gazing. The 'alam and who it represents, and what it is able to "do" through the act of gazing reinforces for the devotee that she is ontologically of a different order compared to the Imams and Ahl-e Bayt. The vows and offerings made before the 'alam are intrinsically intersensorial, dependent on the touch of the devotional gaze.

\section{About the Author}

The author's research focuses on devotional texts, ritual practice, and Shici material practices in South Asia. Ruffle's second monograph Everyday Shicism in South Asia is forthcoming in winter 2021.

\section{References}

Abbas, G. (2018). Evolving Sense of Visualizing the Divine in Popular Islam in Pakistan: An Ethnographic Case Study. South Asian Popular Culture 16 (2-3), pp. 215-33.

Abbas, G. (2017). Visual Challenges Faced by Islam in South Asia in the Modern Era. Al-Adwa 48 (32), pp. 1-12. 
Abbas, G. (2007). Tazias of Chiniot. Lahore: Tarikh Publications.

Allan, J.W. (2012). The Art and Architecture of Twelver Shicism: Iraq, Iran, and the Indian SubContinent. London: Azimuth Editions.

Assmann, J. (2015). Memory and Culture. In: D. Nikulin, ed., Memory: A History, Oxford: Oxford University Press, pp. 325-49.

'Azmi, R. (2000). The Holy Relics at Hyderabad. In: T.H. Wafa, ed., Hyderabad ki Azadari. Translated by Mohammed Taher Bilgrami. Hyderabad: Idara-e-Jaferia, pp. 34-44.

Bakewell, L. (1998). Image Acts. American Anthropologist 100 (1), pp. 22-32.

Baqari, M.H.A. (200o). The Old Ashur Khanas of Hyderabad. In: T.H. Wafa, ed., Hyderabad ki Azadari. Translated by Mohammed Taher Bilgrami. Hyderabad: Idara-e-Jaferia, pp. 50-61.

Bartsch, K., and Kamleh, E. (2014). Karbala in Lucknow: An Itinerary of Architectural Mobility. International Journal of Islamic Architecture 3 (2), pp. 267-302.

Bennett, J. (2010). Vibrant Matter: A Political Ecology of Things. Durham: Duke University Press.

Boivin, M. (2017). Sufism, Pilgrimage, and Saint Worship in South Asia. In: D. Albera and J. Eade, eds., New Pathways in Pilgrimage Studies. New York: Routledge, pp. 53-67.

Boivin, M. (2011). Artefacts of Devotion: A Sufi Repertoire of the Qalandariyya in Sehwan Sharif, Sindh, Pakistan. Karachi: Oxford University Press.

Braünlein, P.J. (2019). Studying Material Religion from a Non-Anthropocentric Perspective? Some Considerations on New Materialisms. Material Religion 15 (5), pp. 622-3.

Buchli, V. (2010). Presencing the Im-Material. In: Bille, M., Hastrup, F., and Flohr, T., eds., An Anthropology of Absence: Materializations of Transcendence and Loss. New York: Springer, pp. $185^{-203 .}$

Chelkowski, P. (2006). Art for Twenty-Four Hours. In: D. Behrens-Abouseif and S. Vernoit, eds., Islamic Art in the 19th Century: Tradition, Innovation, and Eclecticism. Leiden: Brill, pp. 409-21.

Cort, J.E. (2012). Situating Darśan: Seeing the Digambar Jina Icon in Eighteenth- and Nineteenth-Century North India. International Journal of Hindu Studies 16 (1), pp. 1-56.

Deleuze, G., and Guattari, F. (1987). A Thousand Plateaus: Capitalism and Schizophrenia. Translated by Brian Massumi. Minneapolis: University of Minnesota Press.

DiBello, P., and Koureas, G. (2010). Introduction: Other than the Visual: Art, History and the Senses. In: G. Koureas, ed., Art, History and the Senses, 1830 to the Present. London: Routledge, pp. 1-18.

D'Souza, D. (2014). Partners of Zaynab: A Gendered Perspective of Shia Muslim Faith. Columbia: University of South Carolina Press.

Elias, J.J. (2012). Aisha's Cushion: Religious Art, Perception, and Practice in Islam. Cambridge: Harvard University Press.

Elias, J.J. (2007). Un/Making Idolatry: From Mecca to Bamiyan. Future Anterior:Journal of Historic Preservation 4 (2), pp. 12-29.

Fadil, N., and Fernando, M. (2015). Rediscovering the 'Everyday' Muslim: Notes on an Anthropological Divide. HAU: Journal of Ethnographic Theory 5 (2), pp. 59-88.

Flaskerud, I. (2010). Visualizing Belief and Piety in Iranian Shiism. London: Continuum.

Flood, F.B. (2009). Objects of Translation: Material Culture and Medieval "Hindu-Muslim" Encounter. Princeton: Princeton University Press.

Flood, F.B. (2006). Image against Nature: Spolia as Apotropaia in Byzantium and the Dar alIslam. The Medieval History Journal 9 (1), pp. 143-66.

Flood, F.B. (2002). Between Cult and Culture: Bamiyan, Islamic Iconoclasm and the Museum. Art Bulletin 84, pp. 641-59.

Francis, J.A. (2003). Living Icons: Tracing a Motif in Verbal and Visual Representations from the Second to Fourth Centuries C.E. The American Journal of Philology 124 (4), pp. 575-6oo.

Freitag, S. (2007). South Asian Ways of Seeing, Indian Ways of Knowing: The Indian Muslim Niche Market in Posters. The Indian Economic and Social History Review 44 (3), pp. 297-331. 
Frembgen, J.W. (2012). The Horse of Imam Hoseyn: Notes on the Iconography of Shici Devotional Posters from Pakistan and India. In: P. Khosronejad, ed., The Art and Material Culture of Iranian Shi ism: Iconography and Religious Devotion in Shici Islam. London: I.B. Tauris, pp. 179-94.

Ghazali, A.H. (1873). The Alchemy of Happiness, by Mohammed al-Ghazali, the Mohammedan Philosopher. Translated by Henry A. Homes. Albany: Munsell.

Gonda, J. (1969). Eye and Gaze in the Veda. Amsterdam: North-Holland Publishing Company.

Gruber, C., ed. (2019). The Image Debate: Figural Representation in Islam and across the World. London: Gingko.

Gruber, C. (2018). The Praiseworthy One: The Prophet Muhammad in Islamic Texts and Images. Bloomington: Indiana University Press.

Gruber, C. (2016a). Nazr Necessities: Votive Practices and Objects in Iranian Muharram Ceremonies. In: I. Weinryb, ed., Ex Voto: Votive Giving across Cultures. Chicago: University of Chicago Press, pp. 247-75.

Gruber, C. (2016b). Prophetic Products: Muhammad in Contemporary Iranian Visual Culture. Material Religion 12 (3), pp. 259-93.

Haidar, N.N., and Sardar, M., eds. (2015). Sultans of the South, 1500-1700: Opulence and Fantasy. New York: Metropolitan Museum of Art.

Hazard, S. (2013). The Material Turn in the Study of Religion. Religion and Society: Advances in Research 4, pp. 58-78.

Hossain, S. (1990). Tazia: Ephemeral Architecture in India. Mimar: Architecture in Development 35 , pp. 10-17.

Howes, D. (2006). Scent, Sound and Synaesthesia: Intersensoriality and Material Culture Theory. In: C. Tillley, W. Keane, S. Küchler, M. Rowlands, P. Spyer, eds., Handbook of Material Culture. London, Sage, pp. 161-72.

Hutton, D. (2006). Art of the Court of Bijapur. Bloomington: Indiana University Press.

Ibn Ishaq al-'Ibadi, H. (1928). The Book of Ten Treatises of the Eye, Ascribed to Hunain ibn Ishaq (809-877 A.D.): The Earliest Existing Systematic Text-Book of Ophthalmology. Translated by Max Meyerhoff. Cairo: Government Press.

Khosronejad, P., ed. (2012). The Art and Material Culture of Iranian Shicism: Iconography and Religious Devotion in Shi i Islam. London: I.B. Tauris.

Korom, F.J. (2003). Hosay Trinidad: Muharram Performances in an Indo-Caribbean Diaspora. Philadelphia: University of Pennsylvania Press.

Lyons, T. (2015). Some Historic Ta'ziyas of Multan. In: F. Suleman, ed., People of the Prophet's House: Artistic and Ritual Expressions of Shi i Islam. London: Azimuth Editions, pp. 221-31.

McHugh, J. (2011). Seeing Scents: Methodological Reflections on the Intersensory Perception of Aromatics in South Asian Religions. History of Religions $5^{1}$ (2), pp. 156-77.

Meyer, B. (2006). Religious Sensations: Why Media, Aesthetics, and Power Matter in the Study of Contemporary Religion. Amsterdam: Vrije Universiteit.

Mitchell, W.J.T. (2005). There Are No Visual Media. Journal of Visual Culture 4 (2), pp. 257-66.

Mitchell, W.J.T. (1996). What Do Pictures "Really" Want? October 77, pp. 71-82.

Morgan, D. (2014). The Ecology of Images: Seeing and the Study of Religion. Religion and Society: Advances in Research 5, pp. 83-105.

Morgan, D. (2010). The Material Culture of Lived Religion: Visuality and Embodiment. In: J. Vakkari, ed., Mind and Matter: Selected Papers of 2009 Nordik Conference for Art Historians. Helsinki: Helsingfors, 14-31.

Naqvi, A.N. (1974). Azadari: A Historical Review of the Institution of Azadari for Imam Husayin. Karachi: Peermohammed Ibrahim Trust.

Naqvi, S. (2006). The 'Ashur Khanas of Hyderabad City. Hyderabad: Bab-ul-Ilm Society.

Parodi, L.E., ed. (2014). The Visual World of Muslim India: The Art, Culture and Society of the Deccan in the Early Modern Period. London: I.B. Tauris. 
Parsapajouh, S. (2020). The Topography of Corporal Relics in Twelver Shica:Some Anthropological Reflections on the Places of Ziyârâ. Journal of Material Cultures in the Muslim World 1 (2), pp. $195^{-221 .}$

Patel, Y. (2012). Muslim Distinction: Imitation and the Anxiety of Jewish, Christian and Other Influences. PhD Diss., Department of Religious Studies, Duke University.

Pinault, D. (2001). Horse of Karbala: Muslim Devotional Life in India. New York: Palgrave.

Pinault, D. (1992). The Shiites: Ritual and Popular Piety in a Muslim Community. New York: St. Martin's Press.

Promey, S. (2014). Religion, Sensation, and Materiality: An Introduction. In: S. Promey, ed., Sensational Religion: Sensory Cultures in Material Practice. New Haven: Yale University Press, $1-21$.

Ruffle, K.G. (forthcoming). Everyday Shi ism in South Asia. Oxford: Wiley-Blackwell.

Ruffle, K.G. (2017). Presence in Absence: The Formation of Reliquary Shicism in Qutb Shahi Hyderabad. Material Religion 13 (3), pp. 329-53.

Ruffle, K.G. (2015). Wounds of Devotion: Re-Conceiving Mātam in Shici Islam. History of Religions 55 (2), pp. 172-95.

Ruffle, K.G. (2011). Gender, Sainthood, and Everyday Practice in South Asian Shi ism. Chapel Hill: University of North Carolina Press.

Sada-e-Jafaria (200o). The Art and Craft of Making Hyderabadi Standard - The Alams. In: T.S. Wafa, ed., trans. M.T. Bilgrami, Hyderabad ki Azadari. Hyderabad: Idara-e-Jaferia, pp. 108-11.

Sada-ye Ja‘fariyya (1978). Ḥaidarābād men̉ șan`at-e 'alam-sāzī. In: T.S. Wafa, ed., Haidarābād kī 'azādārī. Hyderabad: Mahnama Sada-ye Ja'fariyya, pp. 138-42.

Shaffer, H. (2017). An Architecture of Ephemerality between South and West Asia. Journal 184 East-Southeast. http://www.journal18.org/2054.

Shalem, A. (2015). Amazement: The Suspended Moment of the Gaze. Muqarnas 32, pp. 3-12.

Shalem, A. (2012a). What Do We Mean When We Say 'Islamic Art'? A Plea for the Critical Rewriting of the History of the Arts of Islam. Journal of Art Historiography 6, pp. 1-18.

Shalem, A. (2012b). Dangerous Claims: On the 'Othering' of Islamic Art History and How It Operates within Global Art History. Kritische Berichte: Zeitschrift für Kunst und Kulturwissenschaften 40 (2), pp. 69-86.

Tareen, S. (2020). Defending Muhammad in Modernity. Notre Dame: University of Notre Dame Press.

Wheeler, B. (2014). Collecting the Dead Body of the Prophet Muhammad: Hair, Nails, Sweat and Spit. In: C. Gruber, and A. Shalem, eds., The Image of the Prophet between Ideal and Ideology: A Scholarly Investigation. Berlin: DeGruyter, pp. 45-61.

Wheeler, B. (2006). Mecca and Eden: Ritual, Relics, and Territory in Islam. Chicago: University of Chicago Press.

Zaidi, S. (2016). Religious Iconography in Islam: Some Motifs from the Shica Context in India. India International Centre Quarterly 43 (2), pp. 84-97.

\section{Notes}

1 The tughra is a calligram that is found on the central part of an 'alam known as the peța (belly, girth) where the majority of calligraphy is inscribed. The circular or almond-shaped tughra often references qur'anic verses, the panjetan-e pāk (Muhammad, Fatimah, 'Ali, Hasan, and Husayn), the Shici statement of faith (kalimah) or Allah.

2 Christiane Gruber, ed. (2019). The Image Debate: Figural Representation in Islam and across the World (London: Gingko); Christiane Gruber (2018). The Praiseworthy One: The Prophet Muhammad in Islamic Texts and Images (Bloomington: Indiana University Press); Christiane Gruber (2016a). Nazr Necessities: Votive Practices and Objects in Iranian Muharram Ceremonies, in: Ittai Weinryb, ed., Ex Voto: Votive 
Giving across Cultures (Chicago: University of Chicago Press). pp. 246-75; Christiane Gruber (2016b). Prophetic Products: Muhammad in Contemporary Iranian Visual Culture, Material Religion 12 (3), pp. 259-93; Ghulam Abbas (2018). Evolving Sense of Visualizing the Divine in Popular Islam in Pakistan: An Ethnographic Case Study, South Asian Popular Culture 16 (2-3), pp. 215-33; Ghulam Abbas (2017). Visual Challenges Faced by Islam in South Asia in the Modern Era, Al-Adwa 48 (32), pp. 1-12; Holly Shaffer (2017). An Architecture of Ephemerality between South and West Asia, Journal 184 East-Southeast http:// www.journal18.org/2054; Navina Najat Haidar and Marika Sardar, eds. (2015). Sultans of Deccan India, 1500-1700: Opulence and Fantasy (New York: Metropolitan Museum of Art); Tryna Lyons (2015). Some Historic Ta'ziyas of Multan, in: Fahmida Suleman, ed., People of the Prophet's House: Artistic and Rituals Expressions of Shici Islam (London: Azimuth Editions), pp. 221-31; Avinoam Shalem (2015). Amazement: The Suspended Moment of the Gaze, Muqarnas 32, pp. 3-12; Avinoam Shalem (2012a). What Do We Mean When We Say 'Islamic Art'? A Plea for the Critical Rewriting of the History of the Arts in Islam, Journal of Art Historiography 6, pp. 1-18; Avinoam Shalem (2012b). Dangerous Claims: On the 'Othering' of Islamic Art History and How It Operates within Global Art History, Kritische Berichte: Zeitschrifte für Kunst und Kulturwissenschaften 40 (2), pp. 69-86; Katherine Bartsch and Elise Kamleh (2014). Karbala in Lucknow: An Itinerary of Architectural Mobility, International Journal of Islamic Architecture 3 (2), pp. 267-302; Laura E. Parodi, ed. (2014). The Visual World of Muslim India: The Art, Culture and Society of the Deccan in the Early Modern Era (London: I.B. Tauris); James W. Allan (2012). The Art and Architecture of Twelver Shi ism: Iraq, Iran, and the Indian Sub-continent (London: Azimuth Editions); Finbarr Barry Flood (2009). Objects of Translation: Material Culture and Medieval "Hindu-Muslim" Encounter (Princeton: Princeton University Press); Finbarr Barry Flood (2006). Image against Nature: Spolia as Apotropaia in Byzantium and the Dar al-Islam, The Medieval History Journal 9 (1), pp. 143-66; Deborah Hutton (2006). Art of the Court of Bijapur (Bloomington: Indiana University Press), and Shakeel Hossain (199o). Tazia: Ephemeral Architecture in India, Mimar: Architecture in Development 35, pp. 10-17.

3 Karen G. Ruffle (forthcoming). Everyday Shi ism in South Asia (Oxford: Wiley-Blackwell); Karen G. Ruffle (2017). Presence in Absence: The Formation of Reliquary Shi'ism in Qutb Shahi Hyderabad, Material Religion 13 (3), pp. 329-53; Karen G. Ruffle (2015). Wounds of Devotion: Re-Conceiving Mãtam in Shici Islam, History of Religions 55 (2), pp. 172-95; Diane D'Souza (2014). Partners of Zaynab: A Gendered Perspective of Shia Muslim Faith (Columbia: University of South Carolina Press); Brannon Wheeler (2014). Collecting the Dead Body of the Prophet Muhammad: Hair, Nails, Sweat and Spit, in: Christiane Gruber and Avinoam Shalem, eds., The Image of the Prophet between Ideal and Ideology: A Scholarly Investigation (Berlin: DeGruyter), pp. 45-61; Brannon Wheeler (2006). Mecca and Eden: Ritual, Relics, and Territory in Islam (Chicago: University of Chicago Press); Jamal J. Elias (2012). A'isha's Cushion: Religious Art, Perception, and Practice in Islam (Cambridge: Harvard University Press); Jamal J. Elias (2007). Un/Making Idolatry: From Mecca to Bamiyan, Future Anterior: Journal of Historic Preservation 4 (2), pp. 12-29; Michel Boivin (2011). Artefacts of Devotion: A Sufi Repertoire of the Qalandariyya in Sehwan Sharif, Sindh, Pakistan (Karachi: Oxford University Press); Sandria Freitag (2007). South Asian Ways of Seeing, Indian Ways of Knowing: The Indian Muslim Niche Market in Posters, The Indian Economic and Social History Review 44 (3), pp. 297-331; Sadiq Naqvi (2006). The Ashur Khanas of Hyderabad City (Hyderabad: Bab-ul-Ilm Society); David Pinault (2001). Horse of Karbala: Muslim Devotional Life in India (New York: Palgrave), and David Pinault (1992). The Shiites: Ritual and Popular Piety in a Muslim Community (New York: St. Martin's Press).

4 Jürgen Wasim Frembgen (2012). The Horse of Imam Hoseyn: Notes on the Iconography of Shici Devotional Posters from Pakistan and India, in: Pedram Khosronejad, ed. The Art and Material Culture of Iranian Shicism: Iconography and Religious Devotion in Shici Islam (London: I.B. Tauris), pp. 179-94; Pedram Khosronejad, ed. (2012). The Art and Material Culture of Iranian Shicism: Iconography and Religious Devotion in Shici Islam (London: I.B. Tauris); Ingvild Flaskerud (2010). Visualizing Belief and Piety in Iranian Shiism (London: Continuum); Peter J. Chelkowski (2006). Art for Twenty-Four Hours, in: Doris Behrens-Abouseif and Stephen Vernoit, eds., Islamic Art in the 19th Century: Tradition, Innovation, and Eclecticism (Leiden: Brill), pp. 409-21, and Frank J. Korom (2003). Hosay Trinidad: Muharram Performances in an Indo-Caribbean Diaspora (Philadelphia: University of Pennsylvania Press).

5 In order to minimize confusion and to distinguish the South Asian architectural form from the Iranian dramatic performance genre (ta'ziyeh), I spell the former as ta'ziya.

6 The interview is available in both Urdu and English. For the original Urdu interview, see Sada-ye Ja'fariyya (1978). Ḥaidarābād men̉ șan'at-e 'alam-sāzī. In: T.S. Wafa, ed., Haidarābād kī 'azādārī. Hyderabad: Mahnama Sada-ye Ja'fariyya, pp. 138-42. For the English translation of the interview, see Sada-e-Jafaria (200o). The Art and Craft of Making Hyderabadi Standard - The Alams. In: T.S. Wafa, ed., trans. M.T. Bilgrami, Hyderabad ki Azadari. Hyderabad: Idara-e-Jaferia, pp. 108-11.

7 Diana Eck's groundbreaking study of darśan was one of the first sustained studies of the practice of religious vision in Hindu traditions; Diana Eck (1998). Darśan: Seeing the Divine Image in India, 3rd ed. (New York: Columbia University Press). John Cort's 2012 study of darśan in Digambara Jainism significantly advanced understanding of Indic visual practices, calling attention to their context-specific 
nature, which Eck's study largely ignored; John E. Cort (2012). Situating Darśan: Seeing the Digambar Jina Icon in Eighteenth- and Nineteenth-Century North India, International Journal of Hindu Studies 16 (1), pp. $1-56$.

8 Among the repertoire of relics associated with Lal Shahbaz Qalandar and his shrine (dargāh) in Sehwan Sharif in Sindh, Pakistan is the gulüband, a black stone necklace encased in a silver cover over which pilgrims (zā'irān) pour water and consume for healing purposes, giving it the sobriquet, shifā kā pathar (the healing stone). Multiple traditions circulate about the origins of the black stone and how it came to be associated with Lal Shahbaz. Several of these narratives connect the stone with the fourth Imam, Zayn al-'Abidin, whose intercession South Asian Shi'a seek for his ability to cure illness. According to Michel Boivin by one account, the black stone originated from the Kaba in 684 when a fire damaged the structure during the reign of the villainous 'Umayyad caliph Yazid. The stone fragment was saved by Imam Zayn al-Abidin and passed down in his family, eventually to his descendant Isma il, until it entered into the possession of Lal Shahbaz. In another narrative, at the command of the caliph Yazid, the black stone was placed around Imam Zayn al-'Abidin to wear as a neck shackle (tauq) as he was marched as a prisoner from Kufa to Damascus after the battle of Karbala. The weight of the stone caused the Imam's head to lower as if in submission. Boivin notes that the stone was eventually forsaken over time, and was later retrieved by a pious family of sayyids in conformity with the drama of the reliquary script of lost-found objects, recovered by pious individuals. What is notable is the central place Imam Zayn al-Abidin has in articulation of Shici cultural memory through this object. For further discussion of the gulūband at Sehwan Sharif, see Michel Boivin (2011). pp. 91-6. 